\title{
A PRELIMINARY CENSUS OF THE MACROFUNGI OF MOUNT WELLINGTON, TASMANIA - THE AGARICALES
}

\author{
by David A. Ratkowsky and Genevieve M. Gates
}

(with three tables, one text-figure and one appendix)

\begin{abstract}
Ratkowsky, D.A. \& Gates, G.M., 2002 (31:xii): A preliminary census of the macrofungi of Mount Wellington, Tasmania - the Agaricales. Papers and Proceedings of the Royal Society of Tasmania 136: 89-100. https://doi.org/10.26749/rstpp.136.89 ISSN 0080-4703. School of Plant Science, University of Tasmania, Private Bag 55, Hobart, Tasmania 7001, Australia.
\end{abstract}

\begin{abstract}
The macrofungi of Tasmania are part of a kingdom of living organisms that is poorly known in Australia; most species are unnamed and undescribed. The present work represents an initial attempt at identifying the rich mycobiota of Mount Wellington, one of Tasmania's best-known and most-studied regions for other plant groups. Attention is confined to the 'gilled' fungi, the order Agaricales. The agarics of Mount Wellington comprise a very large group, and in the 15 families recognised, 130 previously named and described species are differentiated and presented here. The true number of species is at least twice that many, as some large families have been inadequately studied in Australia. For example, in the family Entolomataceae, we believe there are over 50 distinct species in the genus Entoloma and at least four species in the genus Rhodocybe on Mount Wellington.
\end{abstract}

Key Words: Macrofungi, Agaricales, agarics, Mount Wellington (Tasmania).

\section{INTRODUCTION}

One of the authors (DAR) has previously been involved in surveys of the phanerogams (Ratkowsky \& Ratkowsky 1976, 1977), bryophytes (Ratkowsky \& Ratkowsky 1982) and lichens (Ratkowsky et al. 1989) of the Wellington Range, near Hobart, Tasmania. This study extends the series of surveys to the order Agaricales of the Kingdom Fungi. Mycologists are not in agreement as to the total number of macrofungal species in Australia, but they do agree that the number of currently named and described species represents only a small percentage of the actual number of species present on the Australian continent. There are few professional taxonomic mycologists in Australia, and revisions of fungal families and/or genera have been slow to appear. Most active Australian mycologists are involved in plant pathology, crop and forest protection, and other activities that offer little or no time for taxonomy. There is, however, much scope for taxonomic work, and revisions of most families and some genera are needed.

The boundaries of the order Agaricales are a subject of disagreement amongst mycologists. Recent work with ribosomal DNA in fungal genes is resulting in major changes in phylogenetic concepts about which families should be placed within, or omitted from, the Agaricales. Some of the changes resulting from this and other recent research are reflected in the ninth edition of the Dictionary of the Fungi (Kirk et al. 2001), which broadens the concept of Agaricales in some respects and narrows it in others. The authors have chosen to follow the classification scheme for genera within families adopted by Bougher \& Syme (1998), except for some minor disagreements as to the placement of some genera. Interested readers wishing to identify gilled fungi seen in the field to the level of genus should consult the present authors' recently published keys to the families and genera of agarics in Tasmania (Ratkowsky \& Gates 2002).

\section{MATERIALS AND METHODS}

\section{Survey Zones}

Mount Wellington, which rises to $1270 \mathrm{~m}$, lies west of Hobart, at $42^{\circ} 54^{\prime} \mathrm{S}, 147^{\circ} 14^{\prime} \mathrm{E}$ (see fig. 1 for a general location map). As the mycobiota of the mountain is greatly reduced in many of the ecological zones in comparison to flowering plants, bryophytes or lichens, the macrofungal survey covered a much smaller area than the previous surveys mentioned in the Introduction. The most frequently visited localities on Mount Wellington were the wet, eastern-facing gullies. The main tracks we used on the east face $\left(42^{\circ} 55^{\prime} \mathrm{S}\right.$, $147^{\circ} 15^{\prime} \mathrm{E}$ ) at elevations between 350 and $720 \mathrm{~m}$ (see the Mount Wellington Walk Map and Notes, Department of Environment and Land Management, Tasmania, 1997, for the track routes) were Fern Glade, Middle, Reids, Pipeline, Jacksons, Betts Vale, Circle, Shoobridge, Lenah Valley, Radfords, Sphinx Rock and Silver Falls. Slightly further to the north (42.54'S, $147^{\circ} 15^{\prime} \mathrm{E}$; elev. 300-580 m) we used Myrtle Gully and Old Farm Trail. The other frequently used tracks were Myrtle Forest Creek above Collinsvale $\left(42^{\circ} 52^{\prime} \mathrm{S}, 1^{\circ} 47^{\circ} 09^{\prime} \mathrm{E}\right.$; elev. $\left.600 \mathrm{~m}\right)$, Truganini $\left(42^{\circ} 56^{\prime} \mathrm{S}\right.$, $147^{\circ} 21^{\prime} \mathrm{E}$; elev. $\left.100-340 \mathrm{~m}\right)$, various trails around the Waterworks Reserve Reservoirs (42054'S, 147º17'E; elev. $200 \mathrm{~m}$ ), and the portion of the track to Cathedral Rock that follows alongside the North West Bay River (42057'S, $147^{\circ} 12^{\prime} \mathrm{E} ; 250 \mathrm{~m}$ ). We also made limited use of several other tracks.

A factor limiting the size of the survey area in comparison to the earlier plant surveys was the extent of vegetation recovery since the 1967 bushfires, making cross-country travel at lower elevations difficult. Following the approach taken by Ratkowsky \& Ratkowsky $(1976,1977)$, the habitat of the Mount Wellington survey area was divided up into zones determined largely by the dominant species of Eucalyptus present. The zones ranged from lowland areas up to 400-500 m elevation of dry sclerophyll on either dolerite or mudstone, to treeless montane shrubberies and grasslands above $1220 \mathrm{~m}$. Very few macrofungi were found 


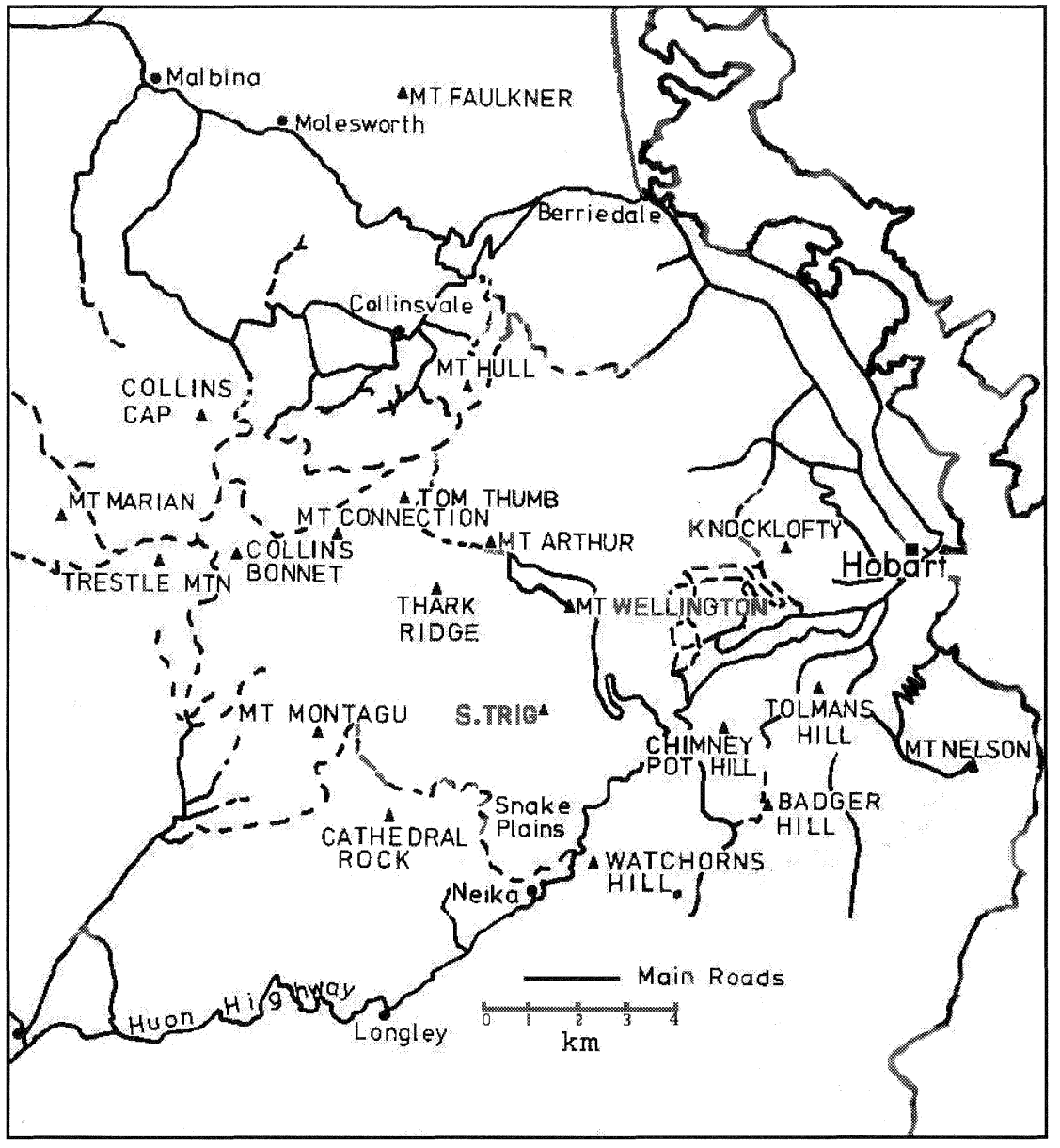

FIG. 1 - Location map of Mount Wellington, showing some of its features. at elevations corresponding to the treeless uppermost zone or the zone containing Eucalyptus coccifera as the sole eucalypt species, and few were also found in the zone dominated by $E$. urnigera. Owing to the scarcity of agarics at the higher altitudes, the Milles, Pinnacle and Ice House Tracks were rarely used.

The most productive zones mycologically were (1) 'gully communities' (up to $600 \mathrm{~m}$ elevation), which are permanently wet and with a thick undergrowth lacking Eucalyptus spp. (except for the steep sides of the gullies, which might support E. regnans in well-drained pockets), but which often contains Nothofagus cunninghamii (Fagaceae), Bedfordia salicina and Olearia argophylla (both Asteraceae), Pomaderris apetala (Rhamnaceae) and Prosanthera lasianthos (Lamiaceae), (2) 'wet sclerophyll forest' (up to $670 \mathrm{~m}$ ) on either Permian or dolerite deposits, the former with Eucalyptus obliqua as the dominant eucalypt species, and the latter, at higher elevations $(600-800 \mathrm{~m})$, dominated by $E$. delegatensis. Other tree or shrub species in the wet sclerophyll include those of the gully communities mentioned above, plus the myrtaceous shrubs Leptospermum scoparium and L. Lanigerum, the wattles Acacia verniciflua and $A$. dealbata (Mimosaceae), Pultenaea juniperina (Fabaceae), Olearia phlogopappa and O. viscosa (Asteraceae), as well as Oxylobium ellipticum (Fabaceae). Few fungi appeared in the dry sclerophyll habitat at lower elevations (up to $500 \mathrm{~m}$ ) dominated by Eucalyptus viminalis and $E$. pulchella on dolerite, except for certain wet gullies within these basically dry environments, such as the Truganini Track in the Cartwright Creek gully below Mount Nelson.
Also productive was the track up Myrtle Forest Creek, which is at an elevation of about $600 \mathrm{~m}$ and wet enough to sustain a large component of rainforest species.

The fieldwork for the project began in January 1994 and is continuing at the time of writing. It is part of a wider program of fungal surveys in southeastern Tasmania. During the first four years of the project, Mount Wellington was visited almost daily (by A. V. Ratkowsky), but between mid-1998 and mid-1999, the authors visited Mount Wellington once or twice a week, and from then to the present time much less frequently, with the emphasis shifting to sites in other parts of Tasmania. Throughout the survey, visits were made in each of the twelve months of the year.

\section{Ecological Comparisons}

The survey was not designed for conducting ecological comparisons, such as between wet and dry sclerophyll sites, between low-altitude and high-altitude sites, or between geological substrates such as sandstone, mudstone and dolerite. However, there is some scope for making comparisons within some sites grouped under the broad headings of wet sclerophyll forests and wet gully communities. The most promising comparison is between Myrtle Gully, a wet gully community, and Old Farm Trail, a fairly open wet sclerophyll environment subject to drying out during periods of low rainfall. These tracks were almost always visited on the same day, usually Myrtle Gully in ascent, followed by Old Farm Trail in descent, enabling a comparison 
to be made with a paired-sample t-test and its nonparametric equivalent, the Wilcoxon signed-rank test.

A less satisfactory comparison can also be made between Myrtle Gully and other wet gullies visited no more than 16 days apart. Because the time span prevents this comparison from being viewed as a paired comparison, a two-sample ttest for independent samples and the nonparametric Wilcoxon-Mann-Whitney and Median tests were used. These tests are included in this paper, at a referee's suggestion, to illustrate some of the possibilities for making ecological comparisons in surveys specifically designed for that purpose. The principal purpose of this paper was to obtain preliminary data on which species of macrofungi were present on Mount Wellington.

\section{RESULTS}

Although about 260 distinct species of agarics were differentiated from the material collected from Mount Wellington, only 130 of these have been validly named and described. The latter species are the ones presented here (see appendix), with the author or authors cited in the usual way. The nomenclature follows May \& Wood (1997), as updated by the interactive catalogue of fungi on the website of the Royal Botanic Gardens Melbourne (www.rbg.vic.gov.au). Wherever possible, references are given to published photographs and illustrations in readily available sources. Where the illustration is only of microscopic characters, this is explicitly stated. Voucher material of each of the species listed in the Appendix is deposited in the Tasmanian Herbarium (HO). In addition, wherever there is sufficient material available, voucher specimens are also placed in the National Herbarium of Victoria (MEL).

Table 1 lists the total number of fungi species, from all orders and families, found in Myrtle Gully and Old Farm

TABLE 1

Comparison of total number of species at Myrtle Gully and Old Farm Trail

\begin{tabular}{lccc}
\hline Date & Myrtle Gully & Old Farm Trail & Difference \\
\hline 09 Mar 99 & 72 & 23 & 49 \\
13 Apr 99 & 73 & 7 & 66 \\
15 Jun 99 & 59 & 19 & 40 \\
06 Sep 99 & 37 & 10 & 27 \\
10 Feb 00 & 4 & 0 & 4 \\
21 Mar 00 & 28 & 5 & 23 \\
18 May 00 & 54 & 4 & 50 \\
22 Jun 00 & 46 & 32 & 14 \\
09 Nov 00 & 60 & 19 & 41 \\
12 Dec 00 & 27 & 4 & 23 \\
09 Jan 01 & 17 & 2 & 15 \\
06 Mar 01 & 7 & 0 & 7 \\
03 May 01 & 102 & 18 & 84 \\
28 Jun 01 & 45 & 4 & 41 \\
31 Jul 01 & 63 & 15 & 48 \\
15 Sep 01 & 59 & 8 & 51 \\
27 Nov 01 & 54 & 13 & 41 \\
17 Jan 02 & 67 & 21 & 46 \\
21 Feb 02 & 59 & 6 & 53 \\
07 May 02 & 29 & 2 & \\
Mean & 48.1 & & 27 \\
\hline
\end{tabular}

Trail, the visits to both sites being made on the same day. Since the number of species on each of the 20 visits was greater at Myrtle Gully than at Old Farm Trail, it is clear that Myrtle Gully is significantly richer, even when a test of low power, such as the Sign test $(p<0.0001)$, is used. The more powerful Wilcoxon signed-rank test and the paired-comparison t-test give similarly low P-values ( $p<$ $0.0001)$. As Myrtle Gully resists drying out to a greater extent than Old Farm Trail, this result is not surprising. A contributory factor to the large difference between sites could be that Myrtle Gully was almost always surveyed in ascent, and Old Farm Trail in descent, and species are more easily seen during the slower pace of ascent. However, this factor is not deemed to be of primary importance.

Seasonal effects are readily apparent from examination of the data entries for any given year, but there is considerable variability from year to year. For example, the early months of 2000 and 2001 were rather dry, leading to a late start to the fungi 'season', whereas in 2002, early rains brought about good numbers in February, followed by a decline in May, when numbers are normally high, owing to a dry March and April. On average over a period of more than three years, the summer months (Dec.-Feb.) produced only 34.8 species in Myrtle Gully, compared with 52.1 in autumn (Mar.-May), 53.3 for winter (Jun.-Aug.) and 52.5 for spring (Sep.-Nov.). Similarly, for Old Farm Trail, the average number of species was lower in summer than in any other season.

Visually, it appeared that, despite the lower total number of species, there were more species of Cortinarius and Russula as a proportion of the total mycobiota along Old Farm Trail than along Myrtle Gully. Table 2 gives the number of species of each of these two genera at the two sites. For Cortinarius, there is no difference between the

TABLE 2

Comparison of Cortinarius and Russula at Myrtle Gully and Old Farm Trail

\begin{tabular}{|c|c|c|c|c|}
\hline \multirow[t]{2}{*}{ Date } & \multicolumn{2}{|c|}{ Cortinarius } & \multicolumn{2}{|c|}{ Russula } \\
\hline & $\begin{array}{l}\text { Myrtle } \\
\text { Gully }\end{array}$ & $\begin{array}{c}\text { Old Farm } \\
\text { Trail }\end{array}$ & $\begin{array}{l}\text { Myrtle } \\
\text { Gully }\end{array}$ & $\begin{array}{c}\text { Old Farm } \\
\text { Trail }\end{array}$ \\
\hline 09 Mar 99 & 10 & 2 & 2 & 2 \\
\hline 13 Apr 99 & 3 & 3 & 5 & 0 \\
\hline 15 Jun 99 & 3 & 4 & 0 & 2 \\
\hline 06 Sep 99 & 0 & 1 & 0 & 1 \\
\hline 10 Feb 00 & 0 & 0 & 0 & 0 \\
\hline 21 Mar 00 & 0 & 0 & 0 & 0 \\
\hline 18 May 00 & 6 & 2 & 3 & 0 \\
\hline 22 Jun 00 & 5 & 11 & 0 & 1 \\
\hline 09 Nov 00 & 5 & 2 & 0 & 1 \\
\hline 12 Dec 00 & 2 & 1 & 2 & 2 \\
\hline 09 Jan 01 & 0 & 0 & 0 & 0 \\
\hline 06 Mar 01 & 0 & 0 & 0 & 0 \\
\hline 03 May 01 & 10 & 8 & 1 & 0 \\
\hline 28 Jun 01 & 1 & 2 & 2 & 0 \\
\hline 31 Jul 01 & 0 & 1 & 1 & 1 \\
\hline 15 Sep 01 & 1 & 0 & 0 & 0 \\
\hline 27 Nov 01 & 1 & 0 & 0 & 1 \\
\hline $17 \operatorname{Jan} 02$ & 0 & 1 & 3 & 4 \\
\hline 21 Feb 02 & 2 & 0 & 2 & 2 \\
\hline 07 May 02 & 0 & 0 & 0 & 0 \\
\hline Mean & 2.45 & 1.90 & 1.05 & 0.85 \\
\hline
\end{tabular}


number of species observed (Wilcoxon signed-rank test, $p$ $=0.287$ ), but when the number is converted into a proportion of the total number of species of all fungi (i.e., number of Cortinarius/total number of species), and the angular transformation is applied to the proportion, there is a significantly higher proportion of Cortinarius in Old Farm Trail than in Myrtle Gully (Wilcoxon signed-rank test, $p=0.007$ ). For Russula, the total number of species clearly does not differ $(p=0.826)$, and after conversion into a proportion and use of the angular transformation, there is only marginal evidence of a higher proportion of Russula in Old Farm Trail than in Myrtle Gully ( $p=$ 0.058). Cortinarius is a genus that is indisputably mycorrhizal, and since Myrtle Gully is almost devoid of eucalypts, whereas they are dominant in Old Farm Trail, this might suggest that Cortinarius is more likely to be found in eucalypt woodlands than in very wet forests or gullies, an explanation that agrees with observations made at other sites in Tasmania.

Table 3 lists the total number of fungi species, from all orders and families, found in Myrtle Gully and in some other gully or wet sclerophyll environments of Mount Wellington (excluding Old Farm Trail) visited no more than 16 days apart. The tests produced only marginal evidence, at most, of higher numbers in Myrtle Gully than in the other site: two-sample t-test $p=0.056$; WilcoxonMann-Whitney test $p=0.079$; Median test $p=0.041$. This suggests that there is not a great difference between various gullies and wet sclerophyll sites that are in close proximity to each other. One factor leading to greater species richness in Myrtle Gully than elsewhere is that the gully is longer and spans a greater altitude range (300-580 m) than any of the other sites.

\section{DISCUSSION}

The 130 species listed in the Appendix is a preliminary attempt at cataloguing the mycobiota (Agaricales) of Mount Wellington, given that only a portion of the agarics have been named. Nevertheless, it should be seen as a beginning, and hopefully, more species will be added as further mycological studies are completed and published. For example, the authors are aware that a study of the genus Mycena in southeastern Australia is soon to be published (C. A. Grgurinovic, pers. comm.), which will increase the number of named species in a genus that is both widespread and abundant in Tasmania, forming a conspicuous component of the mycobiota on wood and litter.

Another work that provides names for five taxa that occur on Mount Wellington is the unpublished thesis of Y. S. Chang (1992). Although these names are not validly published, the author plans to submit them for formal publication (Y. S. Chang, pers. comm.). The five taxa are (1) Pholiota sp. ('pallidocaulis'), a not uncommon species, usually on wood, characterised by a pale coloured upper stipe with conspicuous yellow rhizomorphs at the base, and a pileus that is viscid and scaly, at first light yellow, then brownish orange, becoming light brown throughout. The pleurocystidia do not become yellow in alkaline solution; (2) Pholiota sp. ('viscofumosa'), an uncommon species characterised by a slimy, viscid, smoky grey, striate pileus with concentric whitish scales at the centre, and a whitish, flaky stipe becoming smooth and sordid brown later; (3) Psilocybe sp. ('brunneo-albescens'), a small, often umbonate, species growing on wood, brown at first but becoming whitish with drying, the drying taking place from the centre of the pileus outwards towards the margin;

TABLE 3

Comparison of Myrtle Gully with other wet gullies of Mount Wellington

\begin{tabular}{|c|c|c|c|c|}
\hline $\begin{array}{l}\text { Date visited } \\
\text { Myrtle Gully }\end{array}$ & $\begin{array}{l}\text { No. of species } \\
\text { (Myrtle Gully) }\end{array}$ & $\begin{array}{c}\text { Name of other wet } \\
\text { sclerophyl site }\end{array}$ & $\begin{array}{l}\text { Date visited } \\
\text { other gully }\end{array}$ & $\begin{array}{c}\text { No. of species } \\
\text { (other) }\end{array}$ \\
\hline 09 Mar 99 & 72 & Circle Track & 11 Mar 99 & 48 \\
\hline 13 Apr 99 & 73 & Myrtle Forest Ck. & 15 Apr 99 & 53 \\
\hline 13 May 99 & 18 & Strickland Falls/Lower Sawmill & 13 May 99 & 32 \\
\hline 15 Jun 99 & 59 & Betts Vale & 24 Jun 99 & 42 \\
\hline 12 Aug 99 & 52 & Lenah Valley/Lower Sawmill & 12 Aug 99 & 24 \\
\hline 06 Sep 99 & 37 & Jacksons Bend & 29 Aug 99 & 30 \\
\hline 11 Nov 99 & 45 & Betts Vale & 26 Oct 99 & 19 \\
\hline 30 Dec 99 & 13 & Circle Track & 08 Jan 00 & 23 \\
\hline 10 Feb 00 & 4 & Myrtle Forest & 17 Feb 00 & 33 \\
\hline 21 Mar 00 & 28 & FernGlade & 19 Mar 00 & 4 \\
\hline 22 Jun 00 & 46 & Jacksons Bend & 24 Jun 00 & 31 \\
\hline 09 Nov 00 & 60 & O’Gradys \& Betts Vale & 07 Nov 00 & 31 \\
\hline 12 Dec 00 & 27 & Silver Falls S.T. & 16 Dec 00 & 22 \\
\hline 09 Jan 01 & 17 & Jacksons Bend & 16 Jan 01 & 8 \\
\hline 06 Mar 01 & 7 & N.W Bay River & 10 Mar 01 & 18 \\
\hline 03 May 01 & 102 & Silver Falls S.T. & 05 May 01 & 81 \\
\hline 28 Jun 01 & 45 & Fern Glade & 05 Jul 01 & 49 \\
\hline $31 \mathrm{Jul} 01$ & 63 & Silver Falls S.T. & 02 Aug 01 & 29 \\
\hline 15 Sep 01 & 59 & Myrtle Forest & 25 Sep 01 & 21 \\
\hline 27 Nov 01 & 54 & N.W. Bay River & 17 Nov 01 & 44 \\
\hline 17 Jan 02 & 67 & N.W. Bay River & 01 Jan 02 & 49 \\
\hline 21 Feb 02 & 59 & Jacksons Bend & 19 Feb 02 & 35 \\
\hline 07 May 02 & 29 & Silver Falls S.T. & 11 May 02 & 32 \\
\hline
\end{tabular}


(4) Stropharia sp. ('formosa'), a handsome, large species characterised by a chestnut brown pileus, grey lamellae, and an appendiculate margin, illustrated in Fuhrer \& Robinson (1992, p.59) as Stropharia sp.; and (5) Hypholoma fasciculare (Huds.:Fr.) P.Kumm. var. ('armeniacum'), which has orange lamellae instead of greenish yellow lamellae when young, illustrated in Fuhrer \& Robinson (1992, p.37) as Hypholoma fasciculare.

In addition, one of the present authors (GMG) is working on the taxonomy of the family Entolomataceae in Tasmania, and manuscripts are in preparation in which new species will be published. On Mount Wellington, she has identified 51 distinct species in the genus Entoloma and four species of Rhodocybe, most of which are new to mycology.

\section{ACKNOWLEDGEMENTS}

We pay tribute to the late Ann V. Ratkowsky for her collaboration in the early stages of this project, and to our mentor and teacher, Alan K. Mills, for his guidance, assistance and interest in imparting to us the basic skills and rudiments of mycology.

\section{REFERENCES}

Arora, D., 1986: Mushrooms Demystified. 2nd ed., Ten Speed Press, Berkeley.

Bougher, N.L. \& Syme, K., 1998: Fungi of Southern Australia. University of Western Australia Press, Nedlands, W.A.

Chang, Y.-S., 1992: Taxonomic studies of Strophariaceae (Agaricales) in south-east Tasmania. Unpubl. PhD thesis, University of Tasmania, Hobart.

Cole, M.F., Fuhrer, B.A. \& Holland, A.A., 1984: A Field Guide to the Common Genera of Gilled Fungi in Australia. 2nd ed., Inkata Press, Melbourne.

Courtecuisse, R. \& Duhem, B., 1995: Mushrooms \& Toadstools of Britain \& Europe. HarperCollins, London.

Funrer, B.A., 2001: A Field Companion to Australian Fungi. rev. ed., Bloomings Books, Hawthorn, Victoria.

Fuhrer, B.A. \& Robinson, R., 1992: Rainforest Fungi of Tasmania and South-East Australia. CSIRO, East Melbourne, Victoria.

Gasparini, B., 2001a: A contribution to the knowledge of Cortinarius and allied genera of southern Tasmania, Australia. 1. Cortinarius subgenus Cortinarius. Australasian Mycologist 20: 49-54.

Gasparini, B., 2001b: Cortinarius vinosipes Gasparini sp. nov. Australasian Mycologist 20: 87-91.

Grgurinovic, C.A., 1997: Larger Fungi of South Australia. The Botanic Gardens of Adelaide and State Herbarium and the Flora and Fauna of South Australia Handbooks Committee, Adelaide.

Kirk, P.M., Cannon, P.F., David, J.C. \& STAlpers, J.A., 2001: Dictionary of The Fungi, 9th ed., CAB International, Wallingford, Oxfordshire.
Macdonald, R. \& Westerman, J., 1979: A Field Guide to Fungi of South-eastern Australia. Nelson, Melbourne.

MaY, T.W. \& Fuhrer, B.A., 1995: Nyctalis mirabilis (Fungi: Agaricales), a new species from Australia. Muelleria 8: 385-390.

MAY, T.W.\& WOOD, A.E., 1997: Catalogue and Bibliography of Australian Macrofungi 1. Basidiomycota p.p. (Fungi of Australia, Volume 2a). Australian Biological Resources Study, Canberra.

MiLls, A. \& MonKS, A., 1993: Unusual spore print colouration within the family Hygrophoraceae: two distinctive taxa recorded from Tasmania. Mycotaxon 46: 85-91.

PHILlips, R., 1981: Mushrooms and other Fungi of Great Britain and Europe. Pan Books, London.

Ratkowsky, D. \& Gates, G., 2002: Keys to the Tasmanian families and genera of gilled fungi. Tasmanian Naturalist 124: 2-24.

RatKowsky, D.A. \& RatKowsky, A.V., 1976: Changes in the abundance of the vascular plants of the Mount Wellington Range, Tasmania, following a severe fire. Papers and Proceedings of the Royal Society of Tasmania 110: 63-90.

RatKowskY, D.A. \& RATKOWSKY, A.V., 1977: Plant communities of the Mt. Wellington Range, Tasmania. Australian Journal of Ecology 2: 435-445.

RatKowsKY, D.A. \& RATKOWsKY, A.V., 1982: The bryophytes of the Mt. Wellington Range, Tasmania. Papers and Proceedings of the Royal Society of Tasmania 116: 97-115.

Ratkowsky, A.V., James, P.W., Archer, A.W., Kantvilas, G. \& Ratkowsky, D.A., 1989: Macrolichens of Mount Wellington, Tasmania. Papers and Proceedings of the Royal Society of Tasmania 123: 119-125.

Redhead, S.A., Vilgalys, R., Moncalvo, J.-M., Johnson, J. \& Hopple, J.S., 2001: Coprinus Pers. and the disposition of Coprinus species sensu lato. Taxon 50: 203-241.

Rees, B.J. \& STRID, A., 2001: Relationships between Australian and Northern Hemisphere Gymnopilus species. 1: New species and common misconceptions regarding earlier names. Australasian Mycologist 20: 29-48.

Shepherd, C.J. \& TotTerdell, C.J., 1988: Mushrooms and Toadstools of Australia. Inkata Press, Melbourne and Sydney.

Watling, R. \& Gregory, N.M., 1991: Observations on the boletes of the Cooloola Sand-mass, Queensland and notes on their distribution in Australia: Part 3. Lamellate taxa, Edinburgh Journal of Botany 48: 353-391.

WiluIs, J.H., 1963: Victorian Toadstools and Mushrooms. 3rd ed., The Field Naturalists' Club of Victoria, Melbourne.

Wood, A.E., 1997: Studies in the genus Amanita (Agaricales) in Australia. Australian Systematic Botany 10: 723-854.

Young, A.M., 2000: Common Australian Fungi. rev. ed. University of New South Wales Press, Sydney.

YounG, A.M. \& Wood, A.E., 1997: Studies on the Hygrophoraceae (Fungi, Homobasidiomycetes, Agaricales) of Australia. Ausralian Systematic Botany 10: 911-1030.

(accepted 16 September 2002) 


\section{APPENDIX \\ Species Descriptions of Mount Wellington Agaricales}

Agaricus arvensis Schaeff. - This introduced species, like the 'field mushroom' Agaricus campestris, is encountered on grassy lawns and other disturbed environments. Illustrations: Shepherd \& Totterdell (1988, p. 33); Young (2000, plate 1).

Agaricus austrovinaceus Grgur. \& T.W.May-Characterised by a vinaceous brown, fibrillose pileus. Illustrations: Cole et al. (1984, plate 1), as Agaricus vinacea; Grgurinovic (1997, fig. 341), microscopic characters only.

Agaricus campestris L.:Fr. - This introduced species, like the 'horse mushroom' Agaricus arvensis, is encountered on grassy lawns, such as at the Waterworks Reserve and other disturbed environments. Illustrations: Macdonald \& Westerman (1979, p. 21); Shepherd \& Totterdell (1988, p. 33); Young (2000, plate 1).

Agaricus xanthodermus Genev. - Recognised by an immediate yellow-staining reaction when the base of the stipe is broken. Usually found on lawns in parks, gardens and disturbed areas. Illustrations: Shepherd \& Totterdell (1988, p. 34); Fuhrer (2001, p. 15).

Agrocybe parasitica G.Stev. - Usually growing in clumps on wood of dead trees, characterised by a large, flaring annulus. Illustrations: Macdonald \& Westerman (1979, p. 23), as Agrocybe cylindracea; Fuhrer \& Robinson (1992, p. 22); Fuhrer (2001, p. 16).

Agrocybe pediades (Fr.:Fr.) Fayod - This species group is, like Agrocybe praecox, probably an introduction from the Northern Hemisphere. The small, smooth pileus, $1-3 \mathrm{~cm}$ diam., is hemispherical at first but becomes convex and cracked with age, usually has some shade of brown, and generally lacks an annulus. Usually found in grasslands, on dung or manure, or disturbed land. Illustration: Arora (1986, p. 468).

Agrocybe praecox (Pers.:Fr.) Fayod - The fairly large pileus (3-9 cm diam.) is off-white, pale tan or pale buff, dry or slightly tacky, smooth becoming cracked or fissured in age, is often found growing among woodchips or on dead wood. The thin, membranaceous veil may be fleeting. The species is very variable in all its parts. Illustration: Arora (1986, plate 102).

Amanita effusa (Kalchbr.) D.A.Reid - An easily recognised white species characterised by large pyramidal warts on the pileus. Illustration: Wood (1997, fig. 30).

Amanita muscaria (L.:Fr.) Lam. - The red to orange-red pileus (rarely yellow) covered with white warts make this introduced species one of the most recognisable and most frequently collected and photographed of all agarics. Illustrations: Macdonald \& Westerman (1979, p. 25); Shepherd \& Totterdell (1988, p. 36); Fuhrer \& Robinson (1992, p. 22); Grgurinovic (1997, plate 33b); Young (2000, plate 1).

Amanita ochrophylla (Cooke \& Massee) Cleland Recognised by the dull yellow lamellae, bulbous base and persistent annulus. Illustrations: Grgurinovic (1997, plate 22); Fuhrer (2001, p.
18).

Amanita punctata (Cleland \& Cheel) D.A.Reid Recognised by the grey pileus with striate margin and the large sac-like volva at the base of the stipe. Illustrations: Young (2000, plate 2); Fuhrer (2001, p. 19).

Amanita umbrinella E.J.Gilbert \& Cleland - Characterised by a brownish grey pileus, a smoky grey stipe bearing a prominent, strongly striated annulus, and a friable, fugacious volva. Illustrations: Bougher \& Syme (1998, pp. 170-1); Fuhrer (2001, p. 20).

Amanita xanthocephala (Berk.) D.A.Reid \& R.N.Hilton A small species with an evanescent annulus but usually with a prominent volva and a scarlet, orangered or orange-yellow pileus with striate margin and prominent warts. Illustrations: Shepherd \& Totterdell (1988, p. 37); Grgurinovic (1997, plate 33a); Bougher \& Syme (1998, pp. 172-3); Fuhrer (2001, p. 21).

Anthracophyllum archeri (Berk.) Pegler - This fan-shaped fungus with a much-reduced stipe is brick red or brownish red, and often profusely covers dead branches and twigs. Illustrations: Fuhrer \& Robinson (1992, p. 24); Bougher \& Syme (1998, pp. 190-1).

Armillaria hinnulea Kile \& Watling - Confined to wet gullies and differing from Armillaria novaezelandiae by having a non-glutinous pileus and pink lamellae when mature.

Armillaria luteobubalina Watling \& Kile - Occurs occasionally on the lower slopes of Mount Wellington, bordering the wet forests. Illustrations: Grgurinovic (1997, plate 2c); Bougher \& Syme (1998, pp. 192-3); Fuhrer (2001, pp. 22-3).

Armillaria novaezelandiae (G.Stev.) Herink - Confined to wet gullies where it is abundant and parasitic on wet forest species. Differentiated from Armillaria hinnulea in having a viscid to glutinous pileus with a dark, scaly to punctate centre and whitish lamellae. Illustrations: Macdonald \& Westerman (1979, p. 29), as Armillaria mellea; Shepherd \& Totterdell (1988, p. 39), as Armillaria aff. mellea; Fuhrer \& Robinson (1992, p. 24).

Asterophora mirabilis (May \& Fuhrer) Redhead \& Seifert Species of this genus grow exclusively as a parasite of other agarics, usually on decaying Russula and Lactarius. Illustrations: May \& Fuhrer (1995, p. 387), as Nyctalis mirabilis.

Bolbitius vitellinus (Pers.:Fr.) Fr. - Found in grassy and/or disturbed areas, and recognised by the viscid to glutinous yellow pileus and fragile whitish to pale yellowish stipe. Illustrations: Bougher \& Syme (1998, pp. 230-1); Young (2000, plate 2), as Bolbitius variicolor.

Clitocybe clitocyboides (Cooke \& Massee) Pegler - A funnelshaped species with inflated hyphal elements (vesicles) in the pileus and may be conspecific with Clitocybe phaeophthalma (Pers.) Kuyper [=Clitocybe hydrogramma (Bull. \& Vent.:Fr.) P.Kumm.] of the Northern Hemisphere. Illustrations: Phillips (1981, p. 51), as C. hydrogramma; Courtecuisse \& Duhem (1995, fig. 299), as C. phaeophthalma. 
APPENDIX cont.

Clitocybe semiocculta Cleland - An all-white species growing on wood, usually with dense tufts of white hairs at the base of the stipe. Uncommon. Illustration: Fuhrer \& Robinson (1992, p. 30).

Collybia butyracea (Bull.:Fr.) P.Kumm. - Typically, this soil-borne species has a greasy or soapy feel to the pileus, and a stipe expanded at the base, but it is extremely variable. Illustration: Macdonald \& Westerman (1977, pp. 33). Also known as Rhodocollybia butyracea (Bull.:Fr.) Lennox.

Collybia eucalyptorum Cleland - This species has free, close lamellae and a weak, hollow stipe. Unlike Collybia butyracea, it is found growing directly on wood.

Conchomyces bursiformis (Berk.) E.Horak - The rubbery texture, due to gelatinisation, is a key feature of this white-fleshed, uncommon species, found as eccentrically attached brackets on wood. Illustration: Fuhrer \& Robinson (1992, p. 30).

Coprinus atramentarius (Bull.:Fr.) Fr. - Pileus cylindrical to narrowly oval at first, later becoming upturned. The lamellae are extremely close and thin, later autodigesting. Illustrations: Macdonald \& Westerman (1979, p. 35); Shepherd \& Totterdell (1988, p. 46); Fuhrer (2001, p. 24). Redhead et al. (2001) have transferred this species to Coprinopsis.

Coprinus comatus (O.F.Müll.) Fr. - Pileus cylindrical, surface densely covered with shaggy white to brown scales, autodigesting from below. Illustrations: Macdonald \& Westerman (1979, p. 37); Shepherd \& Totterdell (1988, p. 47); Grgurinovic (1997, plate 34a); Bougher \& Syme (1998, pp. 290-1); Young (2000, plate 5).

Coprinus disseminatus (Pers.:Fr.) Gray - A smallish species usually recognised by the habit of growing in troops on or near wood. Young fruiting bodies are creamy yellow, becoming grey prior to blackening as a result of autodigestion. Illustration: Shepherd \& Totterdell (1988, p. 49); Grgurinovic (1997, plates $3 \mathrm{a}, 3 \mathrm{~b}$ and $34 \mathrm{~b})$; Young (2000, plate 12); Fuhrer (2001, p. 25). Redhead et al. (2001) have transferred this species to Coprinellus.

Cortinarius abnormis Watling \& T.W.May - This allbrown species usually has copious brown velar remains covering the stipe. Illustration: Fuhrer (2001, p. 37).

Cortinarius archeri Berk. - One of the most striking of all members of the genus, this species is readily recognised by the violet, glutinous fruiting bodies. Illustrations: Shepherd \& Totterdell (1988, p. 50); Grgurinovic (1997, plate 15d); Bougher \& Syme (1998, pp. 242-3); Young (2000, plate 6); Fuhrer (2001, p. 30).

Cortinarius australiensis (Cleland \& Cheel) E.Horak - The very large, white fruiting bodies of this species have a membranaceous annulus, reminiscent of Rozites spp., on their stipe. Illustrations: Shepherd \& Totterdell (1988, p. 96), as Rozites austaliensis; Grgurinovic (1997, plate 1a); Bougher \& Syme (1998, pp. 244-5); Fuhrer (2001, p. 32).

Cortinarius austroalbidus Cleland \& J.R.Harris - A white Cortinarius with pale buff hues at maturity and an odour of curry. Illustration: Fuhrer (2001, p. 29).
Cortinarius austroviolaceus B.Gasparini - A striking, concolorous, very dark violet species. Illustration: Gasparini (2001a).

Cortinarius phalarus N.L.Bougher \& R.N.Hilton Characterised by a medium-sized fruiting body with a tawny-brown pileus with white remains from the universal veil and a very distinctive white volva at the base of the stipe. This is one of several closely related volvate species occurring in eastern Australia. Illustration: Bougher \& Syme (1998, pp. 254-5).

Cortinarius rotundisporus Cleland \& Cheel - The deep metallic blue of the pileus, with a yellow-ochre disc, characterises this species. Illustrations: Grgurinovic (1997, plate 10c); Bougher \& Syme (1998, pp. 256-7); Fuhrer (2001, p. 36).

Cortinarius sinapicolor Cleland - The extremely glutinous, mustard-coloured pileus and stipe distinguish this species. Illustrations: Bougher \& Syme (1998, pp. 258-9); Fuhrer (2001, p. 34).

Cortinarius vinosipes B.Gasparini - The distinctive feature of this species is the rose colour that is present throughout the entire fruiting body in the early stage of development. Illustration: Gasparini (2001b).

Crepidotus applanatus (Pers.) P.Kumm. - This brown-spored species, which may attain a diameter of $10 \mathrm{~cm}$ or more, is characterised by a soft, watery texture. Illustrations: Macdonald \& Westerman (1979, p. 43); Fuhrer \& Robinson (1992, p. 30); Fuhrer (2001, p. 40).

Crepidotus variabilis (Pers.:Fr.) P.Kumm. - A small white species that comes in a range of sizes, usually very variable within a single collection; lamellae white at first, prior to maturation of the brown spores. Illustrations: Macdonald \& Westerman (1979, p. 45); Fuhrer \& Robinson (1992, p. 31); Fuhrer (2001, p. 41).

Cyptotrama aspratum (Berk.) Redhead \& Ginn - This wood-inhabiting species is recognised by the orange pileus covered at first with shaggy warts, and the orange colour near the base of the stipe. Illustration: Young (2000, plate 25).

Cystoderma amianthinum (Scop.:Fr.) Konrad \& Maubl. Readily recognised by the mealy granules that cover the stipe below the annulus and the young pileus. Illustration: Fuhrer \& Robinson (1992, p. 31).

Dermocybe austroveneta (Cleland) M.M.Moser \& E.Horak - Recognised by the green cap and yellow stipe, but the colours are extremely variable. Illustrations: Young (2000, plate 6), as Cortinarius austrovenetus; Fuhrer (2001, p. 31).

Dermocybe kula Grgur. - One of several red-coloured species of this genus in Tasmania, this fungus has a dark blood-red pileus and a red stipe. Illustration: Grgurinovic (1997, plate 12b). The illustration in Fuhrer (2001, p. 39), under the name Cortinarius aff. sanguineus, may be of this species.

Dermocybe splendida E.Horak - Characterised by the brilliant paprika-coloured orange-red lamellae. The stipe may be yellow or have varying amounts of red and yellow. Illustrations: Bougher \& Syme (1998, pp. 264-5); Fuhrer (2001, p. 13). 
APPENDIX cont.

Descolea phlebophora E.Horak - Differs from Descolea recedens in the less robust habit and in the spindly stipe with a whitish, rather than a brown, annulus.

Descolea recedens (Cooke \& Massee) Singer - Recognised when young by the abundant light brown floccules that cover the wrinkled pileus and by the striate brown annulus. The lamellae may be straight or crumpled. The species Descolea maculata N.L.Bougher in Bougher \& Syme (1998, pp. 266$7)$, is very similar. Illustrations: Fuhrer $\&$ Robinson (1992, p. 30), as Descolea sp.; Grgurinovic (1997, plate $7 \mathrm{~b}$ ); Young (2000, plate 20), as Pholiota recedens.

Entoloma aromaticum E.Horak - Pileus to $2 \mathrm{~cm}$, conical, buff-pink, hygrophanous, developing a gold sheen, lamellae adnexed to free, pale pink-buff, stipe slender, buff-pink with aeriferous white basal tomentum, odour strong bubblegum or aromatic, taste similar.

Entoloma gelatinosum E.Horak - A robust species, tricholomatoid in stature, pileus to $5 \mathrm{~cm}$, greybrown with pink hues at margin, which disappear rapidly with age, lamellae adnexed, whitish at first, turning pink, stipe stout, grey-brown, tapering downwards. All tissues gelatinised; hence the fruiting body is very lubricous.

Entoloma panniculum (Berk.) Sacc. - Pileus to $3 \mathrm{~cm}$, planoconvex, stunning deep blue-violet, estriate, squamulose, lamellae adnexed, pink, stipe very slender, squamulose, deep blue-violet with aeriferous white basal tomentum.

Entoloma procerum G.Stev. - Pileus to $3 \mathrm{~cm}$, often conical with small sharp umbo, dark chocolate brown, lamellae whitish with brownish hues, margin dark brown, stipe slender, pale off-white or bone with brownish hues and aeriferous white basal tomentum, spores large, twinned tetrahedral.

Entoloma rodwayi (Massee) E.Horak - Pileus to $3 \mathrm{~cm}$, green, translucent striate, becoming brownish with age, drying a blue-green, lamellae flesh pink, stipe pale green with aeriferous white basal tomentum. Illustration: Fuhrer \& Robinson (1992, p. 33).

Entoloma sericellum (Fr.:Fr.) P.Kumm. - Pileus to $3 \mathrm{~cm}$, convex, pure white developing pinkish or ochraceous hues with age, lamellae adnate, pallid pink deepening with age, stipe slender, pure white. Illustration: Fuhrer \& Robinson (1992, p. 32), as Entoloma sp. $c$.

Entoloma viridomarginatum (Cleland) E. Horak - Pileus to $2 \mathrm{~cm}$, dark green, squamulose at the centre, becoming quite orange with age, lamellae pinkorange with hints of green, margin usually dark green or sometimes dark blue, stipe dark green with aeriferous white basal tomentum, slender, stipititrama orange. Illustration: Grgurinovic (1997, fig. 252), microscopic characters only.

Flammulina velutipes (Curtis:Fr.) Singer - Characterised by a caespitose habit on wood and viscid, ochraceous to brown pileus with velvety brown stipe. Illustrations: Shepherd \& Totterdell (1988, p. 24 and p. 57), as Flammulina veluticeps; Fuhrer \& Robinson (1992, p. 35).

Galerina hypnorum (Schrank:Fr.) Kühner - A small species growing amongst moss. Illustrations: Macdonald \& Westerman (1979, p. 47); Fuhrer (2001, p. 43).

Galerina patagonica Singer - The brown pileus usually has an umbonate centre, with the stipe bearing the remains of the partial veil. One of the few species of the genus that is found on wood. Illustration: Grgurinovic (1997, plate 7d); Young (2000, plate 15).

Gymnopilus junonius (Fr.:Fr.) P.D.Orton - A large to very large brown to golden brown species often growing in clusters at the base of eucalypts. Illustrations: Macdonald \& Westerman (1979, p. 49); Shepherd \& Totterdell (1988, p. 59); Fuhrer (2001, p. 45), all as Gymnopilus pampeanus, which was recently reduced to synonymy with $G$. junonius (see Rees \& Strid, 2001).

Hygrocybe astatogala (R.Heim) Heinem. - A conical species extremely variable in colour that may become wholly black from blackish fibrils at maturity, or blacken upon bruising. Illustrations: Fuhrer \& Robinson (1992, p. 38), as Bertrandia astatogala; Grgurinovic (1997, plate 20b).

Hygrocybe aurantiopallens (E.Horak) A.M.Young - A small, dry, apricot-orange species with occasional intervenose lamellae. Illustration: Fuhrer \& Robinson (1992, p. 38), as Camarophyllus aurantiopallens. The photograph on the same page identified as Camarophyllus apricosa is probably the same species, the deep apricot-orange being typical of Tasmanian material.

Hygrocybe cheelii A.M.Young - Pileus dry, bright pinkish mauve or lilac, lamellae mauve-lilac and deeply decurrent, distant and thick, stipe concolorous but yellow at the base. Illustration: Willis (1963, plate 9, fig.1) as Cantharellus lilacinus.

Hygrocybe chromolimonea (G.Stev.) T.W.May \& A.E.Wood - Recognised by the yellow colour with all parts glutinous. Illustration: Fuhrer \& Robinson (1992, p. 41), as Gliophorus chromolimoneus.

Hygrocybe erythrocrenata Monks \& A.K.Mills - Pileus hemispherical, campanulate or conical, brownish red or reddish brown, hygrophanous, becoming pale yellow, then greyish orange on drying, margin pellucid, crenate to subcrenate, lamellae subdecurrent to decurrent, distant, white, whitish, pallid pinkish grey or lilac, stipe red. Illustration: Mills \& Monks (1993, fig. 1c-f).

Hygrocybe firma (Berk. \& Broome) Singer - There are several species of Hygrocybe in Tasmania with a red pileus and a red stipe, which are difficult to distinguish. Hygrocybe firma has a brilliant red-scarlet pileus when fresh, similarly coloured stipe and lamellae, and dimorphic spores. Illustration: Young (2000, front cover). The species illustrated in Fuhrer \& Robinson (1992, p. 44), as Hygrocybe procera, may be the same.

Hygrocybe graminicolor (E.Horak) T.W.May \& A.E.Wood - Pileus and stipe viscid or glutinous, grass-green, lamellae adnate to decurrent, white to pale green, with a fine glutinous thread along the margin. Dries pink. Illustrations: Fuhrer \& Robinson (1992, p. 40), as Gliophorus graminicolor. 


\section{APPENDIX cont.}

Hygrocybe lewellinae (Kalchbr.) A.M.Young - Lilac in all the parts with the pileus split at various places along the margin such that the two faces of a lamella are pulled apart. Illustration: Fuhrer \& Robinson (1992, p. 43), as Humidicutis rosella; Young (2000, plate 8); Fuhrer (2001, p. 48), as Hygrophorus lewellinae.

Hygrocybe lilaceolamellata (G.Stev.) E.Horak - Pileus dry or slightly viscid, brown, lamellae lilac, adnate to decurrent. Illustration: Fuhrer \& Robinson (1992, p. 42).

Hygrocybe mavis (G.Stev.) E.Horak - Concolorous white in all the parts with the pileus split in places along the margin such that the two faces of a lamella are pulled apart. Illustration: Fuhrer \& Robinson (1992, p. 43), as Humidicutis pura.

Hygrocybe miniata (Fr.:Fr.) P.Kumm. - This species differs from Hygrocybe firma in having orange-red to yellowish lamellae. Illustrations: Fuhrer \& Robinson (1992, p. 42); Bougher \& Syme (1998, pp. 178-9). The species illustrated in Fuhrer \& Robinson (1992, p. 42) as Hygrocybe aff. coccinea is part of this complex of species.

Hygrocybe pseudograminicolor A.M.Young - Similar to Hygrocybe graminicolor in the colour of the pileus and stipe and in having a glutinous margin to the lamellae, but the lamellae are yellow-green and the fruiting body remains green rather than becoming pink upon drying. Illustration: Young \& Wood (1997, p. 994).

Hygrocybe reesiae A.M.Young - Pileus, lamellae and stipe pale to intense lilac, lacking pink or yellow tints. Illustration: Young \& Wood (1997, p. 924).

Hygrocybe rodwayi (Massee) A.M.Young - Concolorous cream throughout, pileus dry, convex or becoming plane, occasionally funnel-shaped, margin entire, lamellae decurrent, stipe tapered downwards. Illustration: Fuhrer \& Robinson (1992, p. 39), as Camarophyllus rodwayi.

Hygrocybe stevensoniae T.W.May \& A.E.Wood Recognisable by the viscid or glutinous green pileus and stipe, and white lamellae that lack a glutinous thread on the margin. Dries pink. Illustrations: Fuhrer \& Robinson (1992, p. 41), as Gliophorus viridis; Young (2000, plate 8 ).

Hygrocybe taekeri A.M.Young - Tasmanian material illustrated in Fuhrer \& Robinson (1992, p. 45), as Hygrocybe sp., having a green pileus and stipe with bright orange lamellae with some cross-venation, may be the same as this species described from New South Wales. Illustration: Young \& Wood (1997, p. 1003).

Hygrophoropsis aurantiaca (Wulfen:Fr.) Maire - The feltlike or velvety funnel-shaped pileus is variable in colour from whitish to brown, the lamellae are decurrent, close, some shade of orange or yellow, and may have some dichotomous forking. Illustration: Arora (1986, plate 110). The photograph in Shepherd \& Totterdell (1988, p. 64), attributed to this species, is actually of Paxillus muelleri.

Hygrophorus involutus G.Stev. - Recognised by the pale apricot-yellow viscid pileus, similarly coloured closely spaced lamellae, and a long tapering stipe. There is also an all-white form of the species. Illustrations: Fuhrer \& Robinson (1992, p. 45); the white form of the species is illustrated on p. 39, but misnamed as Camarophyllus niveus.

Hypholoma aurantiaca (Cooke) Faus - Pileus reddish brown or red, and almost always found on woodchips in cultivated areas. Also known as Stropharia aurantiaca (Cooke) P.D.Orton. Illustration: Grgurinovic (1997, plate 28a).

Hypholoma australe O.K.Mill. - Pileus brick to fulvous at the disc, yellowish brown outside the disc, lubricous, lamellae adnate, greenish at first, fairly close, stipe yellowy off-white, imbued with brick hues, squamulose in places with scurfy whitish scales. This species may just be a form of Hypholoma sublateritium. Illustrations: Bougher \& Syme (1998, pp. 232-3); Fuhrer (2001, p. 49).

Hypholoma brunneum (Massee) D.A.Reid - Pileus dark brown with whitish veil remnants around the margin. Usually on wood. Illustration: Fuhrer \& Robinson (1992, p. 36).

Hypholoma fasciculare (Huds.:Fr.) P.Kumm. - Pileus often sulphur yellow with a red-brown or orange-brown centre, stipe concolorous with pileus, lamellae greenish yellow when young. On wood, buried wood or in wood-rich soil, usually caespitose. Illustrations: Macdonald \& Westerman (1979, p. 67); Shepherd \& Totterdell (1988, p. 65); Grgurinovic (1997, plate 4a); Young (2000, plate 17).

Hypholoma sublateritium (Fr.) Quél. - Pileus brick red to orange-brown, stipe white or cream and densely covered with floccules when young, lamellae yellowgreen when young. At the base of trees or on buried wood. Illustrations: Macdonald \& Westerman (1979, p. 69); Shepherd \& Totterdell (1988, p. 66); Fuhrer \& Robinson (1992, p. 36); Young (2000, plate 30).

Inocybe cystidiocatenata Grgur. - Pileus and stipe minutely whitish-hairy. Illustration: Grgurinovic (1997, plate 29c).

Lacrymaria asperospora (Cleland) Watling - Recognised by the fibrillose pileus with appendiculate margin, fringed lamellae and, microscopically, by the distinctive, warted spores. Also known as Psathyrella asperospora (Cleland) Guzmán, Bandala \& Montoya. Illustrations: Shepherd \& Totterdell (1988, p. 92), as Psathyrella asperospora; Bougher \& Syme (1998, pp. 296-7), as Psathyrella asperospora; Young (2000, plate 18); Fuhrer (2001, p. 50).

Lactarius clarkeae Cleland - Pileus and stipe with distinctive apricot-orange colour, and white to cream lamellae that exude latex. Illustrations: Bougher \& Syme (1998, pp. 132-3); Young (2000, plate 18).

Lactarius eucalypti O.K.Mill. \& R.N.Hilton - A smallish, common species recognised by the pinkish to rusty brown colour and readily exuded white latex. Illustrations: Fuhrer \& Robinson (1992, p. 47), as Lactarius aff. subdulcis; Bougher \& Syme (1998, pp. 134-5).

Lepiota haemorrhagica Cleland - The lamellae are creamcoloured, but characteristically turn blood red when bruised. 


\section{APPENDIX cont.}

Lepista nuda (Bull.:Fr.) Cooke - Recognised by the purpleviolet colours of the pileus, lamellae and stipe, this fungus can attain a large size. Found in native forests as well as disturbed habitats. Illustration: Fuhrer (2001, p. 52)

Macrocystidia cucumis (Pers.:Fr.) Josserand - Pileus to 2 $\mathrm{cm}$, conical or convex, red-brown, lubricous, glabrous, margin faintly striate, hygrophanous, lamellae adnexed, ventricose, to $3 \mathrm{~mm}$ deep, pinkcream, stipe very slender, wiry, blackish brown, lighter at apex, strong odour of cod liver or linseed oil, taste of cucumber, cheilocystidia huge. Not previously reported from Australia, Tasmanian material closely fits the description of this Northern Hemisphere species. Illustration: Courtecuisse \& Duhem (1995, fig. 979).

Macrolepiota konradii (Huijsman ex P.D.Orton) M.M.Moser - This species, and other closely related species such as Macrolepiota gracilenta (Krombh.) Wasser, has a confused taxonomy. It is found in disturbed areas or in parks and gardens (e.g., the Waterworks Reserve), but occasionally appears in the bush, usually along roads where there has been disturbance. Illustrations: Macdonald \& Westerman (1979, p. 53), as Lepiota gracilenta; Shepherd \& Totterdell (1988, p. 75); Bougher \& Syme (1998, pp. 186-7); Young (2000, plate 18).

Marasmiellus affixus (Berk.) Singer - This small, fan-shaped fungus, often profusely covering small twigs and bark, is recognised by the strong, unpleasant odour. Illustration: Fuhrer \& Robinson (1992; p. 49).

Marasmius elegans (Cleland) Grgur. - Characterised by the velvety red-brown pileus and the two-toned stipe, whitish above and red-brown below. Illustrations: Macdonald \& Westerman (1979, p. 57); Shepherd \& Totterdell (1988, p. 43), as Collybia elegans; Bougher \& Syme (1998, pp. 202-3); Fuhrer (2001, p. 54).

Melanophyllum haematospermum (Bull.:Fr.) Kreisel - This uncommon species with a greenish or greyish brown spore print is usually placed in the Agaricaceae. The pileus and stipe are granular-mealy and the remains of a veil often hang from the pileus margin. Illustration: Fuhrer \& Robinson (1992, p. 49), as Melanophyllum echinatum.

Melanotus hepatochrous (Berk.) Singer - A small brown pileus and a reduced but distinct stipe characterise this rarely reported, but not uncommon, species growing on rotting wood. Illustration: Shepherd \& Totterdell (1988, p. 54), misidentified as Crepidotus eucalyptorum.

Mycena albidocapillaris Grgur. \& T.W.May - Concolorous white to whitish, pileus very small with striate margin. Illustrations: Shepherd \& Totterdell (1988, p. 82 and Fuhrer \& Robinson (1992, p. 52), both as Mycena subcapillaris. Tasmanian material is in need of further study, as there appears to be more than one species of small, white-coloured Mycena in Tasmania.

Mycena austrofilopes Grgur. \& A.A.Holland - Pileus conical, pale grey or smoky brown, umbo brownish, hygrophanous, lamellae adnexed, pale grey, pellucid, stipe very long and slender, pale grey, basidia twospored.

Mycena austrororida Singer - This is a small species on wood whose stipe is thickly covered with clear gluten and whose whitish pileus may be covered with fine brown dots. Illustration: Fuhrer (2001, p. 57).

Mycena clarkeana Grgur. - This species was segregated from Mycena vinacea Cleland by Grgurinovic (1997). It occurs in clusters on or near wood, rather than soil, and has notched to adnexed lamellae lacking a contrasting margin. Illustrations: Macdonald \& Westerman (1979, p. 63), as Mycena vinacea; Shepherd \& Totterdell (1988, p. 82), as Mycena vinacea; Grgurinovic (1997, plate 17a); Young (2000, plate 19), as Mycena vinacea.

Mycena cystidiosa (G.Stev.) E.Horak - This tall, dark brown species having a long, slender brown stipe with strigose hairs at the base grows on forest litter and is easily recognisable by the abundance of slender, white, rhizomorph-like structures that accompany its appearance. Illustrations: Shepherd \& Totterdell (1988, p. 83), as Mycena aff. eucalyptorum; Fuhrer \& Robinson (1992, p. 53), as Mycena hispida; Grgurinovic (1997, plate 17e).

Mycena epipterygia (Scop.:Fr.) Gray - In Tasmanian material, the pileus is yellowish, fawn or grey, with the stipe usually yellow or lime-green, glutinousviscid, often with cucumber odour when broken. This group has been studied intensively by Grgurinovic (ined.), with one new species, Mycena nyula Grgur. already published (Grgurinovic, 1997) and several others to appear. She considers all Australian material to be different from the true Mycena epipterygia. Illustrations: Shepherd \& Totterdell (1988, p. 80); Fuhrer \& Robinson (1992, p. 50); Young (2000, plate 19); Fuhrer (2001, p. 58 and front cover).

Mycena interrupta (Berk.) Sacc. - The pileus is uniquely sky-blue with a darker centre. On wood. Illustrations: Macdonald \& Westerman (1979, p. 59); Fuhrer \& Robinson (1992, p. 53); Fuhrer (2001, p. 59).

Mycena kurramulla Grgur. - This species is differentiated from other pink-vinaceous species by the combination of subdecurrent, whitish, marginate lamellae and habit on wood. Illustration: Grgurinovic (1997, plate $16 \mathrm{~d})$.

Mycena leaiana (Berk.) Sacc. var. australis Dennis - An uncommon but readily recognised species with bright orange lamella edges. Found on wood. Illustration: Fuhrer \& Robinson (1992, p. 53).

Mycena pura (Pers.:Fr.) P.Kumm. - Pileus and stipe vinaceous purple or purple-brown, pileus margin striate, lamellae concolorous or whitish, lacking a contrasting margin. This species is extremely variable, but it consistently has a radish-like taste and odour and is found on soil. Illustrations: Bougher \& Syme (1998, pp. 204-5); Fuhrer (2001, p. 60).

Mycena sanguinolenta (Alb. \& Schwein. : Fr.) P.Kumm. A brownish red species with marginate lamellae and a stipe that exudes reddish latex when crushed. 
APPENDIX cont.

Illustrations: Shepherd \& Totterdell (1988, p. 58 and p. 82), the former misidentified as Galerina marginata; Grgurinovic (1997, plate 16b); Fuhrer (2001, p. 61).

Mycena subgalericulata Cleland - This often-illustrated species is found on wood, with a conical to convex brown pileus and striate margin, and is probably part of a group in need of further study. Illustrations: Macdonald \& Westerman (1979, p. 61); Shepherd \& Totterdell (1988, p. 81); Bougher \& Syme (1998, pp. 206-7); Young (2000, plate 19).

Mycena viscidocruenta Cleland - Pileus vividly blood red, very viscid to glutinous when moist, and with subdecurrent, marginate lamellae. Illustrations: Macdonald \& Westerman (1979, p. 65); Shepherd \& Totterdell (1988, p. 81); Young (2000, plate 19).

Omphalina chromacea (Cleland) T.W.May \& A.E.Wood A small species characterised by a bright yellow colour and a funnel-shaped pileus. It is one of the few lichen-forming Basidiomycetes. Illustrations: Macdonald \& Westerman (1979, p. 71); Bougher \& Syme (1998, pp. 208-9); Fuhrer (2001, p. 62).

Omphalotus nidiformis (Berk.) O.K.Mill. - This large to very large bioluminescent species with decurrent lamellae may be fan-shaped, shell-shaped or have a depressed centre, with the variable fruiting bodies usually having some purplish grey, cream, and reddish brown blotches. Illustrations: Macdonald \& Westerman (1979, pp. 75), as Pleurotus nidiformis; Shepherd \& Totterdell (1988, pp. 90-1), as Pleurotus nidiformis, Grgurinovic (1997, plates $1 \mathrm{~b}$ and 29d); Bougher \& Syme (1998, pp. 210-1); Young (2000, plates 21 and 26); Fuhrer (2001, pp. 70-1).

Oudemansiella radicata (Relhan:Fr.) Singer - Pileus brownish, viscid to glutinous when young or moist, lamellae very white, and stipe with a long, tapering, rooting base below soil level. Illustrations: Macdonald \& Westerman (1979, p. 73); Shepherd \& Totterdell (1988, p. 85); Bougher \& Syme (1998, pp. 220-1), as Xerula australis, Young (2000, plate 20); Fuhrer (2001, p. 67).

Panellus ligulatus E.Horak - Characterised by small, tongueshaped or spoon-shaped orange fruiting bodies growing on wood. The lack of a blueing reaction of the spores to Melzer's reagent means that the species is uncomfortably placed in Panellus. Illustration: Bougher \& Syme (1998, pp. 212-3).

Panellus longinquus (Berk.) Singer - Readily recognised by the shell-like habit on wood, pink gelatinised viscid pileus and the very reduced stipe. Illustration: Fuhrer \& Robinson (1992, p. 54).

Panellus stipticus (Bull.:Fr.) P.Karst. - This small, woodinhabiting brown fan has lamellae that may be intervenose and that exude a sticky latex. The stipe is short, broad and often greyish. Illustrations: Fuhrer \& Robinson (1992, p. 54); Fuhrer (2001, p. 68).

Paxillus curtisii Berk. - A very soft, but moderately large, white or yellowish fan lacking a true stipe, found on dead wood. The yellow lamellae often have a crinkled appearance.

Paxillus muelleri Berk. - The funnel-shaped pileus and decurrent lamellae with occasional forking characterise this species. Recently renamed as Austropaxillus muelleri (Berk.) Bresinsky \& M.Jarosch. Illustrations (several of which as Paxillus infundibuliformis): Shepherd \& Totterdell (1988, p. 88 and p. 64), the latter misidentified as Hygrophoropsis aurantiaca; Fuhrer \& Robinson (1992, p. 61); Bougher \& Syme (1998, pp. 286-7); Young (2000, plate 20); Fuhrer (2001, p. 82).

Pholiota multicingulata E.Horak - Characterised by distinctive bands of brown scales circling the stipe. However, there are forms of this species that lack these bands or are sparsely or irregularly scaly. See Pholiota squarrosipes (below) for a discussion of microscopic differences. Illustration: Bougher \& Syme (1998, pp. 234-5).

Pholiota squarrosipes Cleland - A medium brown to pale yellowish brown species that has brown scales irregularly placed around the stipe, not in regular bands as in Pholiota multicingulata (above), with which it can be confused. Microscopically the two species are readily separable, as $P$. squarrosipes has small, peg-like, embedded cystidia that become yellow in alkali, whereas P. multicingulata has larger, projecting, mostly hyaline cystidia. Illustration: Shepherd \& Totterdell (1988, p. 89).

Phylloporus rhodoxanthus (Schwein.:Fr.) Bres. - This is probably a species complex (Watling \& Gregory, 1991) and most Tasmanian collections may be referred to this complex. The luteous yellow lamellae, with frequent forking and cross-venation, contrasting with the dark brown, velvety pileus surface of robust habit, are characteristic. Illustrations: Macdonald \& Westerman (1979, p. 89), as Phylloporus hyperion; Grgurinovic (1997, plate 16a).

Pleurotus purpureo-olivaceus (G.Stev.) Segedin - Pileus tongue-shaped or fan-shaped, olivaceous with areas of straw yellow or pale cream, margin inrolled, velvety-fibrillose, lamellae strongly decurrent, some shade of grey, stipe short but well-developed. On decaying, fallen wood, this is an uncommon species in Tasmania.

Pluteus atromarginatus (Konrad) Kühner - Recognised by the pink lamellae when mature, with prominent dark edges to the lamellae, and microscopically by three distinctly different types of cystidia. Illustrations: Bougher \& Syme (1998, pp. 224-5); Young (2000, plate 21).

Pluteus cervinus (Schaeff.) P.Kumm. - Macroscopically very similar to Pluteus atromarginatus (above), but this species lacks the prominent dark edge to the lamellae when mature. Illustration: Grgurinovic (1997, plate 23a).

Psathyrella echinata (Cleland) Grgur. - A brown species found in large numbers on rotting wood. Young specimens may be covered all over with shaggy fibrils. Illustrations: Fuhrer \& Robinson (1992, p. 57), as Psilocybe echinata; Grgurinovic (1997, plate $3 \mathrm{~d} \& \mathrm{e})$.

Psilocybe subaeruginosa Cleland - This variable species has an olive-brown to golden-brown pileus and a white stipe bruising blue. Illustrations: Shepherd \& 


\section{APPENDIX cont.}

Totterdell (1988, p. 93), as Psilocybe sp.; Grgurinovic (1997, plate 4b); Young (2000, plate 22); Fuhrer (2001, p. 73).

Rickenella fibula (Bull. \& Vent.:Fr.) Raithelh. - The small orange to pale orange fruiting bodies are conical to convex at first, becoming centrally depressed later with deeply decurrent lamellae. Usually found growing amongst moss. Illustrations: Grgurinovic (1997, plates 19d and 32c); Bougher \& Syme (1998, pp. 214-5).

Rozites foetens Bougher - Recognised by the membranaceous veil, the shaggy tufts of hair covering the pileus and stipe and very unpleasant odour. Illustration: Fuhrer \& Robinson (1992, p. 56), as Rozites sp.

Russula albonigra (Krombh.) Fr. - Flesh initially white, turning dark grey after bruising or cutting. Tasmanian specimens probably differ from the Northern Hemisphere form of the species, but may be the same as the species illustrated in Bougher \& Syme (1998, pp. 142-3), which they call Russula aff. albonigra.

Russula clelandii O.K.Mill. \& R.N.Hilton - Pileus red to purple, lamellae white or cream-coloured, stipe pink, pileipellis gelatinised. Illustration: Shepherd \& Totterdell (1988, p. 97), as Russula mariae; Bougher \& Syme (1998, pp. 144-5); Young (2000, plate 22), as Russula mariae; Fuhrer (2001, p. 75).

Russula lenkunya Grgur. - This recently renamed and redescribed species has violet colours in the pileus and pink or vinaceous colours in the stipe. The lamellae are described from South Australian material (Grgurinovic, 1997) as being white, whereas those of the Tasmanian material are cream to yellow. Microscopically, they agree in having a ciliate pileipellis of septate hairs subtended by cells, a feature not shared by other Russula species having red, purple or violet in the pileus. Illustration: Grgurinovic (1997, fig. 26), microscopic characters only.
Russula neerimea Grgur. - Pileus buff or yellowy tan with striate-sulcate margin, tacky to viscid when moist, lamellae creamy white, stipe white, odour and taste mild. The macroscopic and microscopic characters suggest that Tasmanian material is the same as this species recently renamed and redescribed from South Australia (Grgurinovic, 1997). Illustrations: Grgurinovic (1997, fig. 36), microscopic characters only; Bougher \& Syme (1998, pp. 152-3).

Russula persanguinea Cleland - Recognised by the red, easily peeled pileus, white stipe and white crowded lamellae. Illustrations: Fuhrer \& Robinson (1992, p. 58), as Russula sp. (b); Grgurinovic (1997, plate 5c); Bougher \& Syme (1998, pp. 154-5); Fuhrer (2001, p. 75).

Simocybe phlebophora E.Horak - Pileus hemispherical in youth, brown, olivaceous or drab, disc coarsely wrinkled upon drying, margin striate, lamellae adnate, brown or greyish, margin fimbriate, stipe some shade of buff, slender, equal, pruinose in the upper half, spores pale brown, smooth, 7-8 x 4-5 $\mu \mathrm{m}$, pileipellis with pear-shaped terminal cells. On wood or soil. Tasmanian material appears to be conspecific with the New Zealand species, as the wrinkled centre to the pileus is distinctive.

Tubaria rufofulva (Cleland) D.A.Reid \& E.Horak - The fruiting body is characterised by its growth on wood and the deep maroon, claret or burgundy red colour throughout, and some traces of the remains of a veil on the stipe. Illustration: Bougher \& Syme (1998, pp. 238-9).

Xeromphalina leonina (Massee) E.Horak - The tiny pale brown pileus of this fungus with decurrent lamellae is conspicuous only because the species tends to form huge colonies on decaying wood. Illustration: Fuhrer (2001, p. 66). 